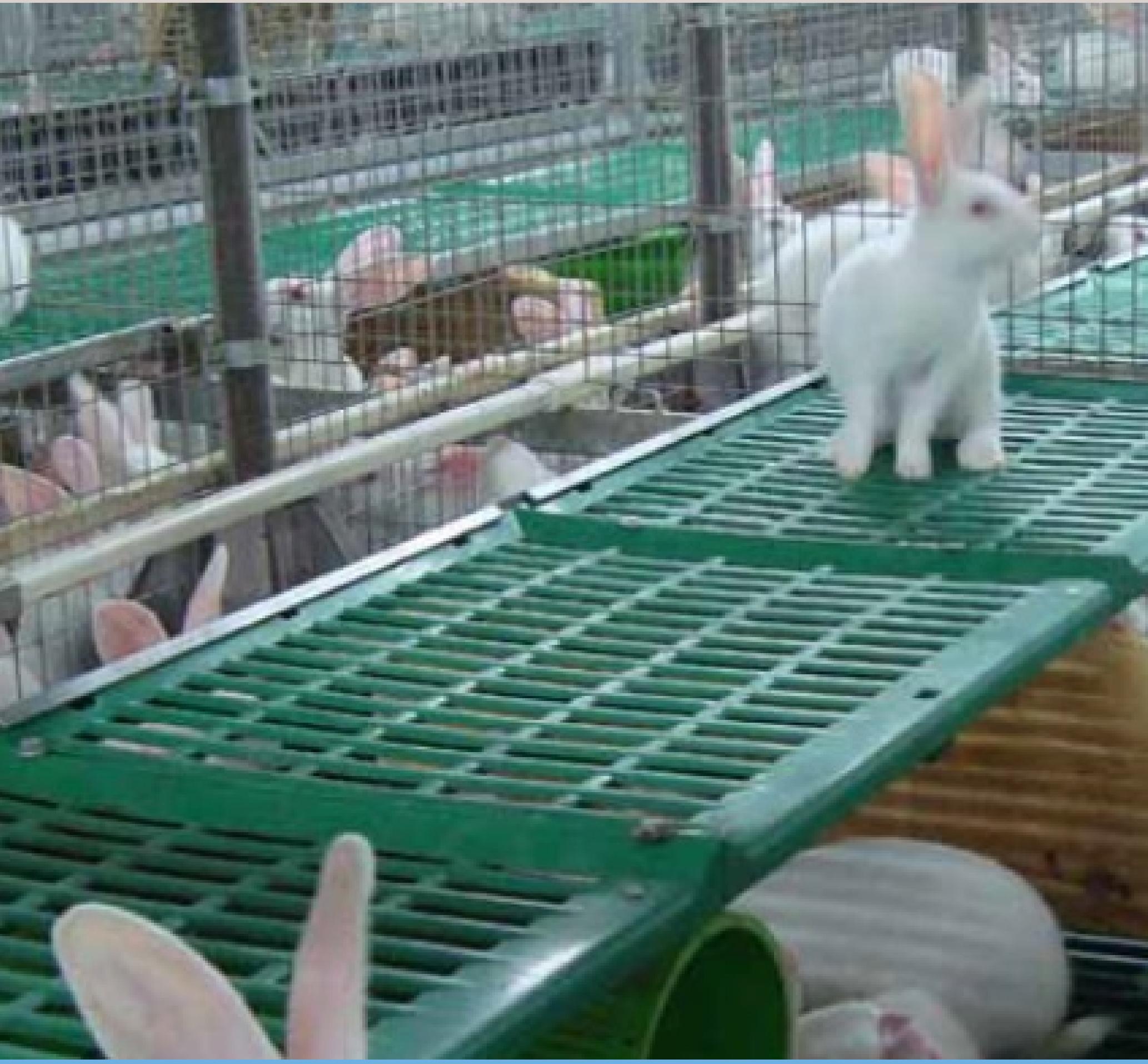

Eindrapportage PPS Duurzame konijnenhouderij 2016-2020 



\title{
Eindrapportage PPS Duurzame konijnenhouderij 2016-2020
}

\author{
Auteurs \\ Dr. Ir. K.H. de Greef \\ Dr. Ing. J.M. Rommers
}

Dit onderzoek is uitgevoerd door Wageningen Livestock Research en gesubsidieerd door het ministerie van Landbouw, Natuur en Voedselkwaliteit, in het kader van het Beleidsondersteunend onderzoek thema 'Gezondheid en welzijn van parkgehuisveste konijnen' (projectnummer BO-47-001-016)

Wageningen Livestock Research

Wageningen, april 2021

Openbaar

Rapport 1307 
Greef de K.H., J.M. Rommers, 2021. Eindrapportage PPS Duurzame konijnenhouderij 2016-2020.

Wageningen Livestock Research, Openbaar Rapport 1307.

Samenvatting NL

Dit rapport behandelt de PPS Duurzame konijnenhouderij, die van 2016 -2020 is uitgevoerd, een door de Topsector Agri \& Food ondersteund initiatief van LTO Vakgroep Konijnenhouderij. Doel van dit programma was om tot een verbetering van dierenwelzijn en diergezondheid te komen en een reductie van antibioticagebruik te bewerkstelligen in de commerciële konijnenhouderij. Tevens werd hiermee invulling gegeven aan de Motie Dekken (2014). Het verbeteren van dierenwelzijn betrof verdere aanpassing van huisvesting van zowel voedsters als vleeskonijnen om beter tegemoet te komen aan de behoeften van de dieren en maatschappelijke wensen. Dit heeft geleid tot een systeem voor parttime groepshuisvesting van voedsters met hun jongen en de verdere overgang naar parkhuisvesting voor vleeskonijnen. De combinatie van deze twee huisvestingsconcepten heeft één ster van het Beter Leven Kenmerk van de Dierenbescherming toegekend gekregen. Het verbeteren van de diergezondheid had met name betrekking op de darmgezondheid van speen- en vleeskonijnen en een reductie van de gezondheidsbelemmeringen van parkhuisvesting. Inmiddels wordt meer dan $70 \%$ van de vleeskonijnen in Nederland in parken gehuisvest. De projectuitvoering omvatte niet alleen regulier praktijkonderzoek en onderbouwend / verdiepend wetenschappelijk onderzoek, maar ook (in toenemende mate) interactieve componenten. Deze werkwijze is voortgezet in een volgende PPS, waarin jongdierzorg centraal staat.

\section{Summary UK}

This report describes the innovation programme "Duurzame konijnenhouderij" [Sustainable rabbit farming] that ran from 2016-2020. The program is an initiative of the farmers group of LTO (the major Dutch farmers organization), supported by the innovation and valorization fund "Topsector Agri \& Food". The objective of the programme was to improve rabbit welfare and health and reduce the use of antibiotics in intensive/commercial rabbit production. Housing conditions were improved by developing a system for housing of rabbit does (with their young) part time in groups and optimization of the housing of meat rabbits to park housing. The combination of these two housing systems was accredited with one star of the "Beter Leven Kenmerk" [an animal welfare hall mark] of the Dierenbescherming, the major Dutch animal protection organization.

Gastrointestinal health issues were addressed as they were an obstacle for the acceptance of park housing of meat rabbits. Nowadays over $70 \%$ of the meat rabbits is kept in parks. The program not only comprised regular applied research and supporting scientific studies, but also an interactive component was introduced. This approach is being continued in a subsequent PPS, which focusses on the care of young rabbits.

Dit rapport is gratis te downloaden op https://doi.org/10.18174/545882 of op www.wur.nl/livestock-research (onder Wageningen Livestock Research publicaties).

\section{(cc) BY-NC}

Dit werk valt onder een Creative Commons Naamsvermelding-Niet Commercieel 4.0 Internationaal-licentie.

(c) Wageningen Livestock Research, onderdeel van Stichting Wageningen Research, 2021

De gebruiker mag het werk kopiëren, verspreiden en doorgeven en afgeleide werken maken. Materiaal van derden waarvan in het werk gebruik is gemaakt en waarop intellectuele eigendomsrechten berusten, mogen niet zonder voorafgaande toestemming van derden gebruikt worden. De gebruiker dient bij het werk de door de maker of de licentiegever aangegeven naam te vermelden, maar niet zodanig dat de indruk gewekt wordt dat zij daarmee instemmen met het werk van de gebruiker of het gebruik van het werk. De gebruiker mag het werk niet voor commerciële doeleinden gebruiken.

Wageningen Livestock Research is NEN-EN-ISO 9001:2015 gecertificeerd.

Wageningen Livestock Research aanvaardt geen aansprakelijkheid voor eventuele schade voortvloeiend uit het gebruik van de resultaten van dit onderzoek of de toepassing van de adviezen.

Op al onze onderzoeksopdrachten zijn de Algemene Voorwaarden van de Animal Sciences Group van toepassing. Deze zijn gedeponeerd bij de Arrondissementsrechtbank Zwolle. 


\section{Inhoud}

$\begin{array}{ll}\text { Woord vooraf } & 5\end{array}$

$\begin{array}{ll}\text { Uitgebreide samenvatting } & 7\end{array}$

$\begin{array}{lr}\text { Inleiding } & 9\end{array}$

$\begin{array}{ll}\text { Rapportage } & 10\end{array}$

$\begin{array}{lll}2.1 & \text { Thema Huisvesting en welzijn } & 10\end{array}$

2.1.1 Huisvesting: Parttime groepshuisvesting van voedsters 10

2.1.2 Huisvesting: Parkhuisvesting vleeskonijnen 12

2.2 Thema Gezondheid en welzijn 13

2.2.1 Gezondheid: Voetzoolbeschadigingen bij voedsters 13

2.2.2 Gezondheid: Hygiëne 14

2.2.3 Gezondheid: Coccidiose 15

2.2.4 Gezondheid: Mengen van jongen uit goede en slechte nesten 15

2.2.5 Gezondheid: RVHD (Rabbit Viral Haemorragic Disease) 16

2.2.6 Gezondheid: Verminderen van afkeuringen vleeskonijnen aan de
slachtlijn

2.2.7 Gezondheid: Voermanagement in relatie tot darmgezondheid /
antibioticareductie

$\begin{array}{lll}2.3 & \text { Thema Markt en sectorontwikkeling } & 19\end{array}$

2.3.1 Markt- en sector ontwikkeling: Beter Leven Keurmerk
Dierenbescherming

2.3.2 Markt- en sector ontwikkeling: Algemeen 19

2.4 Internationaal $\quad 19$

2.4.1 Internationaal: Congresbijdrages WRC en Celle 20

2.4.2 Internationaal: WRSA studiemiddagen Nederland-Belgie 20

2.4.3 Internationaal: Raad Dierenwelzijn België 21

2.4.4 Internationaal: Samenwerking en begeleiding ILVO, België 21

2.4.5 Internationaal: Bezoek Zollikhofen, Zwitserland 22

$\begin{array}{lll}2.5 & \text { Communicatie overig } & 22\end{array}$

2.5.1 Communicatie overig: Begeleidingscommissie PPS 22

2.5.2 Communicatie overig: Overige publicaties vakbladen $\quad 22$

2.6 Nieuwe PPS 2021-2025 (brainstormsessies vitaliteit jonge dieren) 22

$\begin{array}{lll}\text { Bijlage } 1 \text { Verzamelde output } & \mathbf{2 4}\end{array}$

(Semi) Wetenschappelijke artikelen $\quad 24$

$\begin{array}{ll}\text { Rapporten/Notities } & 24\end{array}$

$\begin{array}{ll}\text { Artikelen in vakbladen } & 24\end{array}$

$\begin{array}{ll}\text { Inleidingen/ workshops } & 25\end{array}$ 



\section{Woord vooraf}

Van begin 2016 tot eind 2020 hebben de Nederlandse konijnensector en Wageningen Livestock Research de PPS "Innovatieprogramma Gezondheid en welzijn van parkgehuisveste konijnen" uitgevoerd. Het betrof een initiatief van LTO Nederland, vakgroep Konijnenhouderij, ondersteund door de Topsecto Agri \& Food (AF-15234).

Dit programma omvatte niet alleen regulier praktijkonderzoek en onderbouwend / verdiepend wetenschappelijk onderzoek, maar ook (in toenemende mate) een interactieve component. Meerdere workshops en andere kennissessies zijn gehouden. Met konijnenhouders, dierenartsen, andere erfbetreders en toeleverende en afnemende ketenpartijen. Ook zijn de ambities, de koers en de resultaten besproken met belanghebbenden van buiten de keten, waarbij met name de Dierenbescherming, de Stichting Beter Leven Keurmerk en het Ministerie van LNV genoemd dienen te worden.

Een interactieve opzet als deze is alleen mogelijk bij een constructieve en open houding van de betrokkenen. En deze was er uitdrukkelijk! De initiatiefnemers zijn alle betrokkenen dan ook zeer erkentelijk. En met name verdienen de familie Slegh en de familie Zoontjens hier een uitdrukkelijke vermelding. Vanwege het ruimhartig beschikbaar stellen van hun bedrijf voor experimenten en observaties. En vanwege de bekwame en prettige medewerking met die (soms best veeleisende) onderzoekers in de stal.

Sjef Lavrijsen, Arie Kool en Robbert Bekkers Betrokken Voorzitters LTO Vakgroep Konijnenhouderij 


\section{Uitgebreide samenvatting}

Van 2016 t/m 2020 is de PPS "Innovatieprogramma Gezondheid en welzijn van parkgehuisveste konijnen" uitgevoerd. Het innovatieprogramma betrof een samenwerkingsverband (in PPS-vorm) tussen de konijnensector en Wageningen UR, ondersteund vanuit de Topsector Agri \& Food (TKI AF-15234, 240k€ publieke bijdrage), waarin via kennisbenutting, participatief toegepast èn funderend onderzoek gewerkt is aan de gezondheid en het welzijn van konijnen bestemd voor vleesproductie.

De belangrijkste aanleidingen voor dit onderzoeksprogramma waren 1) de ambitie om de voortgaande lijn in welzijnsverbetering via huisvestingsaanpassing voort te zetten; 2) de uitdaging diergezondheid te bevorderen en het antibioticagebruik verder terug te dringen en 3) follow up geven aan motie van Dekken (2014) over semigroepshuisvesting (hier verder 'part-time groepshuisvesting').

De belangrijkste aandachtspunten betroffen:

- $\quad$ Part-time groepshuisvesting voor voedsters.

Resultaten tonen aan dat het technisch mogelijk is om voedsters met hun jongen het laatste deel van de lactatie in groepen te huisvesten. Vanwege de resulterende rangordegevechten is het onvermijdelijk dat enkele procenten van de voedsters wonden oplopen. Dit leidt tot een dilemma binnen het welzijnsdomein: beoogd welzijnsvoordeel door het meer sociaal houden van de dieren tegenover angst en pijn door de onderlinge gevechten.

> Door ketenpartijen en de Dierenbescherming is een Beter leven (één ster) systeem ontwikkeld met het part-time groepshuisvesten van voedsters als basis. Dit is inmiddels enkele jaren op beperkte schaal door de markt opgepakt.

- $\quad$ Wegnemen van belemmeringen voor de overschakeling naar parkhuisvesting voor vleeskonijnen.

Diverse aspecten van parksystemen zijn getoetst, vergeleken en aangepast op het gebied van tegemoet komen aan de behoeften van de dieren, arbeidsgemak, reinigbaarheid, technische prestaties etc. Inmiddels zijn de parken redelijk uitontwikkeld en is het management er op aangepast. > Op een aanzienlijk deel van de bedrijven functioneren de parken qua productiviteit en gezondheid (vrijwel) vergelijkbaar met het traditionele systeem. Naar schatting $70-80 \%$ van de vleeskonijnen in parken gehouden onder gecertificeerde omstandigheden.

- $\quad$ Analyse van oorzaken van gezondheids-gerelateerde afkeuringen aan de slachtlijn. Resultaat van de verkenningen en onderzoeken aan dit thema hebben vooral aangetoond dat het optreden van abcessen (vooral vanwege Pasteurella spp.) qua oorzaak en preventie uiterst complex en grotendeels onbegrepen is. Het belangrijkste advies (volgend uit het multifactoriële karakter van de aandoening) is huidbeschadigingen te voorkomen (portes d'entrées) en zowel systematische en incidentele suboptimale houderijfactoren te reduceren.

$>$ Het bewustzijn en de aandacht voor dit probleem is gegroeid. De resultaten variëren (onbegrepen) sterk tussen bedrijven en rondes.

- $\quad$ Gezondheidsmanagement op het bedrijf: o.a. interne pathogeenversleping en voermanagement.

Antibiotica worden bij vleeskonijnen vooral ingezet tegen maagdarmproblemen. Preventiemaatregelen die onderzocht zijn betreffen hygiëne, versleping via jongen uit besmette nesten en voermanagement.

$>$ De prevalentie van de belangrijkste darmaandoening ('dikkebuikenziekte') is aanzienlijk gedaald gedurende de laatste jaren. Naar inschatting vooral dankzij het vrij algemeen toepassen van kwantitatieve voersturing (de voerverstrekking via een dagelijkse curve in tijd beperken). 
- $\quad$ Integratie van beschikbare kennis over RVHD-bestrijding en -preventie.

Met de dierenartsen die actief zijn in de konijnensector is kennis, ervaringen en adviezen uitgewisseld en gecombineerd op het gebied van het rondwarende RVHD2-virus.

$>$ Het resulterende gezamenlijke beeld is gedeeld met de konijnenhouders, en er is een gezamenlijk ent-advies gepubliceerd.

- $\quad$ Pijnlijke voetzoolaandoeningen: evaluatie van de effectiviteit van de geïmplementeerde huisvestingsaanpassing.

Voetzoolaandoeningen behoorden tot de belangrijkste welzijnsproblemen bij voedsters. In 2009 zijn in Nederland matjes verplicht gesteld om dit probleem uit te bannen.

> Monitoring in 2019 op een viertal bedrijven heeft bevestigd dat de matjes zeer effectief zijn in het voorkómen van pijnlijke voetzolen.

Hiernaast is aandacht besteed aan kleinere ad hoc vragen vanuit het ministerie en de sector.

De resultaten zijn hoofdzakelijk gedissemineerd in twee kanalen: de periodiek van de konijnensector (Konijnenwijzer, ca 25 artikelen) en in de internationale wetenschappelijke omgeving. Participatie, adoptie en bewustwording van konijnenhouders is (naast de artikelen in de in de Konijnenwijzer) bevorderd via thema-avonden, workshops en bijdragen op discussieavonden. In de internationale contacten is (naast het delen van de technische resultaten) het Nederlandse model van welzijnsverbetering (zelfregulering om tot de welzijnskooi te komen, verbeteren van de kooibodems, overschakeling naar parken, ontwikkelen van groepshuisvestingsarrangementen, ontwikkeling van een marktsegment) verspreid en geduid vanuit de innovatiecontext.

De PPS is door de participanten als succesvol geëvalueerd, en heeft een vervolg gekregen met een (inmiddels gestarte) PPS, die vooral gefocust is op jongdierzorg en het verkennen van het sociaaleconomisch toekomstperspectief voor jonge konijnenhouders.

\section{Aanleidingen voor dit onderzoeksprogramma}

1) De ambitie om de voortgaande lijn in welzijnsverbetering via huisvestingsaanpassing voort te zetten Mede door dit innovatieprogramma zijn verbeteringen doorgevoerd aan de uitvoering en het management van parken voor vleeskonijnen. Eerdere huisvestingsaanpassingen zijn bevestigd in hun effectiviteit qua dierenwelzijn (en dit is internationaal gerapporteerd). En, niet in het minst, naast de 'reguliere' huisvesting in welzijnskooien en parken is een technisch haalbare groepshuisvestingsmethode voor voedsters doorontwikkeld, praktijkrijp gemaakt en gecertificeerd.

2) De uitdaging diergezondheid te bevorderen en het antibioticagebruik verder terug te dringen Het antibiotica-gebruik is aanzienlijk gedaald (met stabilisering sinds 2017). Bijdrage van deze PPS daarin is moeilijk te kwantificeren, maar de reductie van de gezondheidsproblemen geassocieerd aan parkhuisvesting èn het door de sector breed toegepaste voermanagement zijn belangrijke technische factoren.

3) Follow up geven aan motie van Dekken (2014) over semigroepshuisvesting

De resultaten van de pilots, experimenten en monitoring geven aan dat groepshuisvesting van voedsters technisch mogelijk is, met dien verstande dat 1) er voor ca dag 23 zorgen zijn over de kwetsbaarheid van de jongen; 2) de onvermijdelijke rangordegevechten tussen voedsters leiden tot enkele dagen angst en onrust en (ook na de aanvankelijke schermutselingen) enkele procenten beschadigde voedsters. De afweging tussen de voor- en nadelen voor de betreffende dieren is sterk afhankelijk van de gekozen welzijnsbeschouwing. Het onderzoek heeft slechts beperkt aandacht besteed aan wat de consequenties voor management en bedrijfseconomische gevolgen van het alternatieve huisvestingssysteem zijn. Wel is door samenwerking van de Dierenbescherming en ketenpartijen een BLK*-erkenning en een marktarrangement tot stand gebracht. 


\section{$1 \quad$ Inleiding}

Wageningen Livestock Research besteedt al decennia substantieel aandacht aan onderzoek in de konijnenhouderij. Oorspronkelijk middels opdrachten vanuit de overheid (via het Ministerie van LNV) en de sector (via de Productschappen). Sinds 2016 is dit grotendeels geïntegreerd: het onderzoek vindt plaats in de vorm van een Publiek-Private Samenwerking (PPS) van de overheid met LTO en marktpartijen. Naast dit relatief grote account worden door WLR regelmatig kleinere activiteiten en projecten uitgevoerd voor diverse partijen. De huidige rapportage beoogt de hoofdlijn van het onderzoek gedurende de afgelopen 5 jaar (2016-2020) te schetsen.

De rapportage is, na een korte introductie van de PPS, thematisch opgebouwd:

1) Huisvestingsonderzoek (m.n. groepshuisvesting voedsters en parkhuisvesting vleeskonijnen)

2) Gezondheidsonderzoek (m.n. coccidiose, VHD, afkeuringen, voetzoolaandoeningen)

3) Sector- en markontwikkeling (m.n. Beter Leven keurmerk)

4) Overige onderzoeksactiviteiten

\section{De PPS Innovatieprogramma Gezondheid en welzijn van parkgehuisveste konijnen}

Van 2016 tot eind 2020 heeft de PPS Duurzame konijnenhouderij gelopen. Dit werk betrof $70-80 \%$ van de WLR-konijnen-portefeuille. De PPS was een samenwerking tussen WLR en LTO-vakgroep konijnenhouderij, met een overheidsbijdrage vanuit de Topsector Agro\&Food. Doel van deze PPS was om te komen tot een verduurzaming van de commerciële konijnenhouderij door belemmeringen weg te nemen om konijnen integraal in parkhuisvesting te houden en antibioticagebruik te verminderen. Dit geeft de konijnensector zowel maatschappelijk als economisch toekomst. Het project ontwikkelde houderijsystemen voor voedsters en vleeskonijnen die het mogelijk hebben gemaakt om verbeterd dierenwelzijn te verwaarden in meerwaardemarkten, en sloot daarmee aan op de ambitie om dierenwelzijn aanzienlijk te verbeteren, en belemmeringen daarvoor weg te nemen. Gedurende het project schakelde de sector grotendeels over op parkhuisvesting voor vleeskonijnen, en werd een parttime groepshuisvestingssysteem voor de voedsters met jongen praktijk- en marktrijp gemaakt en kwam een Beter Leven Keurmerk hiervoor tot stand. Bij het terugdringen van het antibioticagebruik lag de nadruk op het onderzoeken van mogelijkheden om de darmgezondheid te verbeteren. Belangrijkste invalshoeken waren hygiëne, cocciodosebeheersing en door beter voermanagement het voer beter af te stemmen op de voederbehoefte van met name speen- en vleeskonijnen en daarmee de gezondheid van de dieren te verbeteren en het antibioticagebruik te verminderen.

Het onderzoek binnen de PPS is begeleid door een begeleidingscommissie die ca jaarlijks bijeenkwam en waarin voortgang en richting van de activiteiten werd besproken. Daarnaast vond ca tweewekelijks overleg plaats tussen WLR en de opdrachtgever (voorzitter LTO-vakgroep konijnen) waarin de dagelijkse gang van zaken van het project werden besproken en richting aan het onderzoek werd gegeven.

De output van dit project is met de sector en andere belanghebbende gedeeld in de vorm van artikelen in de KonijnenWijzer, congresbijdragen, artikelen in World Rabbit Journal en in de vorm van PowerPoints op studiemiddag/avonden met o.a. konijnenhouders en teruggekoppeld aan de opdrachtgevers in de vorm van jaarrapportages. 


\section{Rapportage}

\subsection{Thema Huisvesting en welzijn}

\subsubsection{Huisvesting: Parttime groepshuisvesting van voedsters}

\section{Aanleiding}

Aanleiding voor dit onderzoek was de wens vanuit de overheid en de Dierenbescherming om te komen tot groepshuisvesting van voedsters om daarmee beter te voldoen aan de behoefte aan sociale interactie van de dieren. Konijnen zijn sociale dieren, die in een rangorde leven. Sinds 1999 is onderzoek uitgevoerd naar mogelijkheden van volledige groepshuisvesting van voedsters. In eerste instantie in een grondhok onderzocht met acht voedsters die door middel van een elektronisch herkenning systeem toegang hadden tot een eigen nestkast. Een drietal bedrijven heeft hiermee een jaar lang geëxperimenteerd. Geconcludeerd werd dat deze vorm van huisvesting geen toekomstperspectief had door de hoge kosten, hoge arbeidsinzet, slechte hygiëne en controlemogelijkheden en onderlinge agressie van voedsters. In de jaren daaropvolgend is onderzoek gestart naar de mogelijkheden om voedsters pas op een later tijdstip (vanaf 11 dagen na werpen) te mengen, de zogenaamde "parttime" groepshuisvesting. Uit dit onderzoek kwam naar voren dat mengen na 18 dagen na werpen de beste resultaten geeft, maar dat onderlinge agressie nog steeds een knelpunt is. Dit is de aanleiding geweest om in deze PPS verder onderzoek te doen naar mogelijkheden van parttime groepshuisvesting. Met name door onderzoek in combihokken, die het individuele systeem van welzijnskooi combineren met groepsgewijze parkhuisvesting na menging.

\section{Doelstelling}

Het hoofddoel was om obstakels weg te nemen die toepassing van groepshuisvesting van voedsters in de praktijk belemmeren. In de gangbare houderij worden voedsters individueel met hun jongen gehuisvest. Parttime groepshuisvesting van voedsters (waarin voedsters vanaf ca drie weken na werpen tot spenen bij elkaar worden geplaatst) biedt de mogelijkheid tot sociaal contact. Knelpunt is agressie tussen voedsters die optreedt na mengen om de rangorde vasttestellen. Agressie kan leiden tot huidbeschadigingen. Eerder onderzoek toonde aan dat het koppelen van (welzijns)kooien leidde tot onacceptabele niveaus van beschadigingen door rangordegevechten, vooral veroorzaakt door gebrek aan uitwijkmogelijkheden. Parkhuisvesting lijkt goede mogelijkheden te bieden (Rommers et al., 2014). Agressie lijkt te kunnen worden verminderd door het aanbieden van ruimte, voldoende vluchten schuilmogelijkheden (Rommers et al., 2014).

\section{Werkwijze en resultaten}

Met een pilot-benadering is op kleine schaal op het proefbedrijf van de fam. Slegh een aantal opeenvolgende korte proeven uitgevoerd in combihokken waarbij de voedsters met jongen werden gemengd rond dag 20 van de lactatie. Verschillende parklay-outs zijn getest in kleine pilots. Focus lag op vermindering van huidbeschadigingen van voedsters en de gezondheid van de jongen zowel voor als na spenen. De nadruk lag de op de inrichting van het hok (aanbieden van vluchtmogelijkheden voor voedsters en jongen), aanwezigheid crèche, leeftijd jongen bij mengen, hokbezetting en het al dan niet verplaatsen van voedsters.

In tegenstelling tot eerder onderzoek (pilots in 2014) was de groepshuisvesting in parken probleemloos voor de jongen. Bij elke park-indeling bleek onderling beschadigend gedrag van de voedsters op te treden. In een grotere proef zijn de meest belovende parklay-outs getest. Hierbij zijn twee verschillende hoklay-outs vergeleken (met en zonder aanwezigheid van nestkastafscheidingen) en zijn vluchtmogelijkheden op twee verschillende manieren in het systeem aangeboden ( $p v c$ pijp in dwars- of lengterichting onder het plateau bevestigd). Uit de resultaten blijkt dat agressie tussen voedsters optreedt, en dat circa $5 \%$ van de voedsters ernstige beschadigingen oplopen. De hoklay-out waarin nestkastwanden waren verwijderd (en dus betere vluchtmogelijkheden gaf) bleek (in tegenstelling tot de resultaten in de laatste pilot) niet minder beschadigingen te geven. Uitval van 
jongen tijdens de zoogperiode en na spenen gaf geen problemen. De resultaten van de

laatstgenoemde proef zijn gepubliceerd in de KonijnenWijzer en in een wetenschappelijk tijdschrift.

Vervolgens is in 2018 het werk aan parttime groepshuisvesting van voedsters verbreed naar een vijftal praktijkbedrijven. Hier zijn pilots uitgevoerd met kleinere aantallen voedsters in parken. Aspecten die deze pilots naar voren brachten betroffen beschadigingen, achterblijven van jongen en zorg over de conditie van de voedsters. Belangrijke vraag was of de leeftijd van de jongen bij mengen van invloed is op het succes. De ervaringen liepen nogal uiteen. Begin 2019 is een workshop/bijeenkomst georganiseerd met de konijnenhouders die de pilots in 2018 uitvoerde om ervaringen te delen en te bekijken wat de volgende stappen kunnen zijn. Door de verschillen tussen bedrijven en ondernemers vraagt dit maatwerk. Per bedrijf is besproken welke problemen speelden, en daarop lag de focus in 2019. De ervaringen zijn aan de hand van een telefonische enquête geïnventariseerd. Individuele konijnenhouders hebben op hun bedrijf acties uitgezet om specifieke problemen of zorgen aan te pakken. O.a. volgen van voedsters qua gewichtsontwikkeling en aanvullende bescherming van jongen. In samenwerking met Victoria Mengvoeders is ook in 2019 op een vijftal andere praktijkbedrijven in pilotvorm ervaring opgedaan met parttime groepshuisvesting van voedsters. Vervolgens is in een groter experiment Victoria's Babyparksysteem onderzocht met parttime groepsgehuisveste voedsters.

Binnen dit werkpakket is ook meegewerkt aan het formuleren en implementeren van het Beter Leven keurmerk, waarvan parttime groepshuisvesting de grootste aanpassing op het reguliere systeem betrof.

\section{Outcome}

- In 2017 is door de Dierenbescherming een voorlopige set criteria geformuleerd voor een één ster Beter Leven erkenning (BLK*). In 2018 en 2019 zijn de eerste commerciële batches konijnen geproduceerd onder de BLK-criteria en naar de retail gegaan. Dit is in 2020 gecontinueerd.

\section{Communicatie (mondeling)}

- $\quad$ Studieclub konijnenhouders en groepshuisvesting.

Op 24 november 2016 heeft Jorine Rommers een studie-avond verzorgd voor de studiegroep Vrouwelijke Organisatie van Konijnenhouders (VOK) met als titel: Voedsters en groepshuisvesting? Mogelijkheden en knelpunten op basis van gedrag. Van deze studiebijeenkomst is een artikel in de KonijnenWijzer gepubliceerd en een PowerPoint aanwezig.

- $\quad$ Meerdere bijeenkomsten met konijnenhouders die meewerkten aan pilots.

Output

- Jorine Rommers en Karel de Greef, 2017. Parttimegroepshuisvesting van voedsters, pilotonderzoek. KonijnenWijzer, jaargang 35, augustus 2017: 8-11.

- $\quad$ Rommers J. and de Greef K., 2017. Towards part-time group-housing of lactating rabbit does? In: Proceedings 20th International Symposium of housing and diseases of rabbits, furproviding animals and pet animals, 17-18 May, Celle: 3-13.

- $\quad$ Rommers J., 2017. Voedsters en groepshuisvesting? Mogelijkheden en knelpunten op basis van gedrag. KonijnenWijzer, jaargang 35, februari 2017: 14-19.

- $\quad$ Rommers, J.M. en Greef, K.H. de, 2018. Are combi parks just as useful as regular parks for fatteners for part-time group housing of rabbits does? World Rabbit Science 26: 299 - 305.

- $\quad$ Rommers, J.M. en K.H. de Greef, 2018. Zijn combi-parken even geschikt als parken voor parttime groepshuisvesting van voedsters? KonijnenWijzer 36-1: p.10-13.

- $\quad$ Rommers J.M. en K.H. de Greef, 2019. Opgang komen met groepshuisvesting van voedsters vraagt maatwerk. KonijnenWijzer 37, 1: 23.

- $\quad$ Rommers J., 2017. Voedsters en groepshuisvesting? Mogelijkheden en knelpunten op basis van gedrag. KonijnenWijzer, 34, februari: p. 14-19.

- $\quad$ Rommers J., 2017. Voedsters en groepshuisvesting? Mogelijkheden en knelpunten op basis van gedrag. Inleiding op de studieavond vrouwelijke konijnenhouders (VOK) PowerPoint. 
- $\quad$ Rommers, J. 2017. PPS Duurzame konijnenhouderij. Toelichting op het lopende onderzoek naar groepshuisvesting van voedsters Afdeling Dierenwelzijn WLR + PowerPoint.

\subsubsection{Huisvesting: Parkhuisvesting vleeskonijnen}

\section{Aanleiding}

Geïnitieerd door praktijk-initiatieven en gestimuleerd door marktvraag is in het afgelopen decennium een parkhuisvestingssysteem voor vleeskonijnen in de konijnenhouderij geïntroduceerd. In deze vorm van huisvesting worden grotere aantallen vleeskonijnen (circa 25-40 dieren) in hokken (geen kooien) gehuisvest in plaats van de reguliere welzijnskooien, waarbij verrijking wordt aangeboden om beter tegemoet te komen aan het natuurlijke gedrag van konijnen. Het hok heeft een kunststof vloer (meestal volledig, minimaal $80 \%$ ), een plateau, twee of drie dichte schotten en een of twee kunststof buizen als vluchtgelegenheid en ter verbetering van het ligcomfort. Daarnaast hebben de dieren continu de beschikking of ruwvoer en knaaghout om verveling tegen te gaan en aan hun knaagbehoefte te voldoen.

In de praktijk circuleerden signalen dat zowel de productiviteit als de gezondheid van konijnen in parkhuisvesting achterbleef bij het voorheen gebruikelijke systeem (afmesten in welzijnskooien).

\section{Doelstelling}

Doel van het onderzoek was om nadelen van de parken (productiviteit, gezondheid) weg te nemen, om zo de introductie van parkhuisvesting te bevorderen.

\section{Werkwijze en resultaten}

Drie merken commercieel beschikbare parksystemen zijn getoetst aan de behoeften van dieren en aan gezondheidsaspecten.

De bestaande parksystemen waarvan documentatie beschikbaar was (Van Eck, Menenghin en Jansen) zijn in een deskstudie getoetst. Tevens is een systeemvergelijking op een praktijkbedrijf uitgevoerd. Deze systeemvergelijking had als primaire vraagstelling of er verschillen waar te nemen zijn tussen de beschikbare parksystemen qua prestaties op het gebied van hygiëne, productiviteit en gezondheid.

De drie parksystemen (Meneghin, Van Eck en Jansen/JLSE) zijn op een commercieel konijnenbedrijf in dezelfde afdeling geplaatst en vergeleken qua productiviteit (gewichten), bevuiling (scores), reinigbaarheid (ervaringen konijnenhouder, tijdsbesteding, scores) en gezondheidsresultaten (uitval, geobserveerde gezondheidsafwijkingen).

De drie parksystemen bleken vergelijkbaar te presteren qua productiviteit en gezondheid. Dit gold zowel in de eerste ronde waarin zich aanzienlijke gezondheidsproblemen voordeden, als in de tweede, meer normale ronde. Met de werkgroep Zicht op Gezonde Konijnen is de technisch-experimentele benadering aangevuld met een interactieve sessie. Konijnenhouders hebben de systemen gestructureerd beoordeeld op een aantal aspecten. Deze zijn vervolgens plenair besproken. De resultaten van de systeemvergelijking zijn in overall rapport vastgelegd, en in een serie artikelen in 2017 in de KonijnenWijzer verspreid.

In het kader van het werken met vleeskonijnen in parken is in het verleden een flyer met management tips gemaakt. Deze flyer is nogmaals gepresenteerd in de KonijnenWijzer.

\section{Outcome}

Momenteel (2020) worden circa $70-80 \%$ van de vleeskonijnen in Nederland in parken gehuisvest. Op een groot deel van de bedrijven blijken parken (vrijwel) vergelijkbaar te presteren als het oorspronkelijke systeem.

\section{Communicatie (mondeling)}

\section{- $\quad$ Studieavond konijnenhouders}

Op 17 januari 2017 is er een studie-avond verzorgd voor konijnenhouders met betrekking tot de evaluatie van parksystemen voor vleeskonijnen. Van deze studie-avond is een PowerPoint beschikbaar. 
- $\quad$ Jorine Rommers, Ingrid de Jong, Wim Houwers, Theo van Hattum en Karel de Greef, 2017. Evaluatie van parkhuisvestingssystemen voor vleeskonijnen. WLR Rapport 1018.

- Jorine Rommers, Ingrid de Jong, Karel de Greef, 2017. Evaluatie van parkhuisvesting van vleeskonijnen. Voldoen de parksystemen aan de behoeften van konijnen? KonijnenWijzer, jaargang 35, mei 2017: 7-11.

- Jorine Rommers, Henk Gunnink, Theo van Hattum, Karel de Greef, 2017. Evaluatie van parkhuisvesting van vleeskonijnen. Hoe presteren de konijnen in de verschillende parksystemen? KonijnenWijzer, jaargang 35, mei 2017: 13-17.

- Jorine Rommers, Wim Houwers, Karel de Greef, 2017. Evaluatie van parkhuisvesting van vleeskonijnen. Verschillen de parksystemen in hygiëne en reinigbaarheid? KonijnenWijzer, jaargang 35, augustus 2017: 13-17.

- Jorine Rommers en Karel de Greef, 2017. Evaluatie van parkhuisvesting van vleeskonijnen. Verschillen de parksystemen in werkbaarheid? KonijnenWijzer, jaargang 35, augustus 2017: 19-21.

- Maertens L., Rommers J.M., 2016. Het huisvesten van vleeskonijnen in parken. KonijnenWijzer, jaargang 34, mei: 14-15.

- $\quad$ Rommers J. en de Greef K., 2017. PowerPoint t.b.v. studieclub konijnenhouders gehouden op 17 januari 2017 m.b.t. evaluatie parkhuisvesting voor vleeskonijnen.

\subsection{Thema Gezondheid en welzijn}

\subsubsection{Gezondheid: Voetzoolbeschadigingen bij voedsters}

\section{Evaluatie na 10 jaar gebruik van kunststof matjes}

\section{Aanleiding}

1) Sinds 2009 is een kunststof matje op de gaasbodem in de voedsterkooien verplicht gesteld om ernstige voetzoolbeschadigingen (pododermatitis) bij voedsters te voorkomen. Na introductie is er geen systematische monitoring of inventarisatie geweest om na te gaan in hoeverre de matjes voldoen;

2) Vanuit Duitsland kwamen signalen dat met name vleeskonijnen die gehuisvest werden op een volledig alternatieve bodem (kunststof roosters met beperkte doorlaat) ernstige voetzoolbeschadigingen opliepen.

Vanwege deze signalen uit Duitsland èn vanuit de vraag of de aanpassing van 10 jaar geleden effectief is, is monitoring van voetzolen van voedsters en vleeskonijnen opgezet en opgestart.

\section{Doelstelling}

In kaart brengen of de veranderde vloeruitvoering de gewenste vermindering van voetzoolaandoeningen bij voedsters opgeleverd heeft.

\section{Werkwijze en resultaten}

In 2019 zijn vier konijnenbedrijven bezocht, waarbij op elk bedrijf de voetzolen van de achterpoten van 100 voedsters en van vleeskonijnen uit twee parken zijn beoordeeld op beschadigingen. De resultaten van het onderzoek lieten zien dat er nauwelijks ernstige voetzoolbeschadigingen bij voedsters werden aangetroffen. In deze praktijkevaluatie is ook bevestigd dat pododermatitis niet voorkomt bij vleeskonijnen onder de Nederlandse omstandigheden (vloeruitvoering). De matjes blijken te voldoen om pododermatitis bij voedsters te voorkomen. De uitkomsten zijn gecommuniceerd met de konijnenhouders door middel van een artikel in de KonijnenWijzer, een presentatie op de WRSA studiemiddag en de evaluatie is als wetenschappelijke bijdrage ingestuurd voor het World Rabbit Congress in Nantes (Frankijk) in 2020 (congres is uitgesteld naar 2021).

\section{Outcome}

$\mathrm{Er}$ is nu formele bevestiging dat de veranderde vloeruitvoeringen de eerder geconstateerde voetzoolproblemen van voedsters vrijwel opgelost hebben. Tevens is bevestigd dat de in Nederland 
gebruikelijke vloeruitvoering niet leidt tot de voetzoolproblemen bij vleeskonijnen zoals die in

Duitsland (met andere wetgeving qua doorlaatbaarheid roosters) optreden.

Output

- $\quad$ Rommers J.M. en K.H. de Greef, 2019. Voetzoolbeschadigingen: een evaluatie na 10 jaar kunststof matjes. KonijnenWijzer 37, 3: 17.

- $\quad$ De Greef K.H. en Rommers J.M., 2019. Het vóórkomen van voetzoolproblemen bij commerciële konijnen op Nederlandse bedrijven. Voorlopige resultaten. PowerPoint bijdrage op de gezamenlijke studiedag WRSA voor de Belgische en Nederlands leden op 17 april 2019.

- $\quad$ Rommers J.M. and de Greef K.H., accepted. Are plastic mates effective for diminishing footpad lesions of rabbit does? - Survey after 10 years in The Netherlands. World Rabbit Congres, Nantes (short paper ingediend in 2020, congress is uitgesteld naar juni 2021).

\subsubsection{Gezondheid: Hygiëne}

\section{Aanleiding}

Adequate reiniging en desinfectie wordt gezien als een belangrijke factor in het reduceren van besmettingsdruk, en daarmee het optreden van (m.n. darm-)gezondheidsaandoeningen en verhoogd antibioticagebruik. Bij de introductie van parksystemen ontstonden nieuwe vragen op dit gebied. Om deze reden is hygiëne van parksystemen als een van de werkpakketen opgenomen in de PPS 20162020. Parken hebben volledig plastic bodems en lijken moeilijk reinigbaar. De onderzoeksaandacht voor de hygiëne en reinigbaarheid van de in de proef opgenomen parken is onderdeel geweest van de vergelijking van parksystemen (zie onder welzijn en huisvesting parkhuisvesting vleeskonijnen).

\section{Doelstelling}

Hoe is de kwaliteit van reiniging objectief en waardevol vast te stellen?

\section{Werkwijze en resultaten}

Het onderzoek is deels uitgevoerd door een studente van de Faculteit Diergeneeskunde, mede begeleid vanuit IRAS Universiteit Utrecht. $E r$ is een methode ontwikkeld om de kwaliteit van reiniging in beeld te krijgen. De methode is experimenteel getoetst in combinatie met het parksysteemvergelijkingsexperiment. Naast de reguliere kiemgetalbepalingen is speciale aandacht gegeven aan achtergebleven sporen (Clostridia) en is verkend of reductie van de biofilm op de huisvestingsonderdelen onderdeel van het reinigingsprotocol dient te zijn.

De resultaten van hygiëne-onderzoek geven aan dat een professionele reiniging en desinfectie tot goede hygiëne-resultaten kan leiden, en dat een visuele beoordeling voldoende is om de kwaliteit van reiniging op hoofdlijn te beoordelen. Van het onderzoek van de studente is een stageverslag en een artikel in de KonijnenWijzer verschenen. Er zijn contacten gelegd met bedrijven die enzym-gebaseerde middelen voor verwijderen biofilm beschikbaar hebben.

\section{Outcome}

Het bewustzijn van het belang en de complicaties van de reinigbaarheid van parken is toegenomen, vooral door het groepsgewijs beoordelen van parken door konijnenhouders. Het thema Hygiëne heeft, op aangeven van de klankbordgroep, geen verdere inzet binnen de PPS meer gehad.

\section{Output}

- $\quad$ Eijkelenboom N., 2016. The development and use of a hygiene assessment system in a commercial rabbit farm. Stageverslag, Universiteit Utrecht, Faculteit Diergeneeskunde.

- $\quad$ Eijkelenboom N., 2016. Stagerapportage: Hygiëne in de konijnenhuisvesting. KonijnenWijzer, jaargang 34 , augustus: 7-8. 


\subsubsection{Gezondheid: Coccidiose}

\section{Aanleiding}

Coccidiose-besmettingen worden gezien als een belangrijke predisponerende factor bij

darmaandoeningen. Adequate coccidiosebestrijding is daarmee een van de instrumenten bij het reduceren van antibioticagebruik. In de jaren voor aanvang van de PPS 2016-2020 is hier onderzoek aan gepleegd, deels samen met Victoria Voeders. Bedoeling was ook in de huidige PPS hier onderzoeksinput op on te zetten.

\section{Doelstelling}

Verbeterde diagnostiek, bewustzijn bij konijnenhouders en inzicht in managementmaatregelen die de coccidiose-impact verminderen

\section{Werkwijze en resultaten}

Dit onderdeel is elk jaar laag op de prioriteit gezet, en daarmee niet vanuit het onderzoek opgepakt. Vanuit de industrie zijn wel initiatieven opgepakt.

\subsubsection{Gezondheid: Mengen van jongen uit goede en slechte nesten}

\section{Aanleiding}

In parkhuisvesting van vleeskonijnen worden na spenen de jongen uit verschillende nesten gemengd. Slechte jongen worden bij spenen veelal uitgeselecteerd, maar de gezond ogende jongen uit slechte nesten worden aangehouden. In hoeverre deze jongen gezondheidsrisico's vormen voor de overige jongen in een park (door transmissie van pathogenen) is onbekend. Met een experiment is gepoogd hier een antwoord op te krijgen, en om bewustzijn voor versleping van pathogenen te bevorderen.

\section{Doelstelling}

Heeft het mengen van goede en minder goede nesten invloed op de diergezondheid?

\section{Werkwijze en resultaten}

Als gezondheidsmanagement-experiment zijn in een deel van de parken binnen de systeemvergelijking (zie Huisvesting en parkhuisvesting vleeskonijnen) 2 konijnen uit minder goede nesten bijgemengd in (uiterlijk bezien) gezonde nesten. Ter vergelijking is een aantal andere parken bevolkt met uitsluitend uiterlijk gezonde konijnen uit goede nesten. De uitval in beide proefgroepen is gevolgd. Gezond ogende konijnen afkomstig uit probleemnesten bleken een aanzienlijk hogere uitvalskans te hebben gedurende de afmestperiode. Dit bevestigde de hypothese dat er veterinair gezien carry over effecten vanuit de zoogperiode naar de afmestperiode zijn. De hypothese dat er een ongunstig effect op hun hokgenoten zou zijn werd niet bevestigd - de productiviteit en gezondheidsprestatie van de overige konijnen was niet aantoonbaar verschillend voor de parken met en zonder konijnen uit verdachte nesten. Gezonde konijntjes uit slechte nesten lijken na spenen de totale uitval in het park niet te beïnvloeden, echter de uitval van deze groep konijntjes zelf is in de afmestperiode wel hoger dan konijntjes die uit goede nesten komen. De resultaten van dit onderzoek zijn gerapporteerd in de KonijnenWijzer en op het Wereldcongres van de WRSA in China. Daarnaast heeft een studente Dierwetenschappen WU een deskstudie verricht op basis van dit onderzoek, waarbinnen een literatuurstudie is uitgevoerd met betrekking tot dit onderwerp en statistiek op de uitval van bovengenoemd experiment is verricht. Hiervan is een stageverslag verschenen.

\section{Outcome}

Bewustzijn dat pathogeenversleping een rol speelt bij spenen, en dat managementprocedures hier op in kunnen grijpen.

\section{Output}

- $\quad$ Rommers J.M., Greef K.H de, Houwers H.W.J., Hattem T.G. van, 2016. Goed ogende konijnen uit slechte nesten wat doen we ermee in parkhuisvesting? KonijnenWijzer, jaargang 34, mei: 10-12.

- $\quad$ Rommers J.M., Greef K.H. de, 2016. Are pre-weaning health problems transferred to later phases in PARC housed meat rabbits? In: Proceedings of the 11th world rabbit congress, Qingdao, June 1518, 2016, Q. Yinghe, L. Fuchang and T. Gidenne (eds), p. 579-582. 
- $\quad$ Laarhoven J., 2020. The Effect of Mixing Kits from Poor and Healthy Litters on Post-Weaning Mortality in Parc-Housed Fattening Rabbits. MSc thesis, WUR.

\subsubsection{Gezondheid: RVHD (Rabbit Viral Haemorragic Disease)}

\section{Aanleiding}

Rabbit Heamorrhagic Disease is een virusziekte die bij konijnen voorkomt en een hoge sterfte geeft met name onder de vleeskonijnen. De moederdieren worden op de bedrijven geënt en zijn daardoor beschermd evenals de jonge konijntjes tot circa 3-4 weken leeftijd. Er zijn twee varianten RHD1 en RHD2. Sinds enkele jaren zijn er regelmatig uitbraken van RHD type 2 in de konijnensector. Met name RHD2 geeft op de commerciële konijnenbedrijven veel problemen, met name door ziekte en uitval van vleeskonijnen.

\section{Doelstelling}

In het laatste deel van de PPS heeft de begeleidingscommissie WLR gevraagd een coördinerende rol op zich te nemen in het bijeenbrengen van de praktijkervaringen en veterinaire adviezen hieromtrent.

\section{Werkwijze en resultaten}

In 2019 is een begin gemaakt met een Quick scan literatuur en door ervaringen van betrokken dierenartsen te verzamelen. Er zijn drie bijeenkomsten georganiseerd met dierenartsen die actief zijn binnen de commerciële konijnenhouderij. In de eerste bijeenkomst lag de focus op preventie en vaccinatiestrategie. In de tweede bijeenkomst lag de nadruk op best practices ten aanzien van RHD2 en in de derde bijeenkomst zijn de verschillende vaccinatie strategieën tegen het licht gehouden. Van elk van de bijeenkomsten is een verslag gemaakt en van de eerste bijeenkomst zijn de bevindingen gerapporteerd in een artikel in de KonijnenWijzer. Het artikel met betrekking tot het entschema zal in 2021 in de KonijnenWijzer worden gepubliceerd.

\section{Outcome}

Ge-update entadvies ten behoeve van RVHD2 voor konijnenhouders

Output

- $\quad$ Drie (interne) verslagen van de drie bijeenkomsten met dierenartsen en PowerPoint.

- $\quad$ De Greef K., 2020. RVHD2: Vier samen weten meer dan een alleen..... KonijnenWijzer 38, 4: 30.

- $\quad$ Arts H., Claessens A., Willems J., 2021. Bescherming tegen RVHD type 2. KonijnenWijzer 39, 1: 1315.

\subsubsection{Gezondheid: Verminderen van afkeuringen vleeskonijnen aan de slachtlijn}

\section{Aanleiding}

Sinds de huisvesting van vleeskonijnen in parken wordt een toename van met name abcessen aan de slachtlijn gerapporteerd. Afkeuringen zijn doorgaans een indicator van onderliggende gezondheidsproblemen, èn elk afgekeurd konijn vertegenwoordigt een aanzienlijke derving en daarmee kostenpost. Alle arbeid, voer en verdere input die gepleegd is, is dan voor niets geweest.

\section{Doelstelling}

Op grond van signalen uit de sector heeft de vakgroep aan Wageningen Livestock Research gevraagd te inventariseren hoe groot het probleem is, te onderzoeken of er oorzaken aan te wijzen zijn, en wat eventuele maatregelen zijn om het aantal afkeuringen te verminderen.

\section{Werkwijze en resultaten}

In Nederland is er geen grotere slachterij meer voor konijnen en vrijwel $99 \%$ (CBS 2020) van de vleeskonijnen worden geslacht in Belgische slachterijen. Een Belgische slachterij was bereid de afkeuringsrapportages met ons te delen en van 17 bedrijven zijn de gegevens verkregen. Aan de hand van de afkeuringsdata van de koppels is inzichtelijk gemaakt welk soort afkeuringen het betrof, welke verschillen er tussen bedrijven waren en of er een patroon zichtbaar was (o.a. bedrijf, seizoen, fokritme). Er was duidelijk verschil in bedrijven in het percentage afkeuringen, dat varieerde van 
beneden $1 \%$ tot bijna $4 \%$, waarbij circa $90 \%$ van de afkeuringen inderdaad abcessen waren. Het fokritme leek van invloed. Deze resultaten zijn teruggekoppeld met de individuele konijnenhouders. Vervolgens is er een workshop gehouden met konijnenhouders, waarin de resultaten zijn gedeeld en besproken wat er tot dusver verzameld is vanuit het onderzoek. Slachthuizen zijn bezocht met een dierenarts en keuringsinstanties zijn geconsulteerd. Daarnaast zijn visies en factoren besproken die de konijnenhouder kan beïnvloeden om het aantal afkeuringen te verminderen. Resultaat van de verkenningen en onderzoeken aan dit thema hebben vooral aangetoond dat het optreden van abcessen (vooral vanwege Pasteurella spp.) qua oorzaak en preventie uiterst complex en grotendeels onbegrepen is. Het belangrijkste advies (volgend uit het multifactoriële karakter van de aandoening) is om huidbeschadigingen te voorkomen (reductie portes d'entrées) en om zowel systematische en incidentele suboptimale houderijfactoren (waaronder onrust) te reduceren.

\section{Outcome}

De aandacht voor het onderwerp is uitdrukkelijk bevorderd. Concrete resultaten anders dan dat dit probleem sterk bedrijfs- en ronde-afhankelijk is, en een typisch 'alles prima in orde hebben is het beste advies maar geen garantie'-probleem is. Afzonderlijke konijnenhouders zijn verder gegaan met de aanpak van dit probleem.

\section{Communicatie (mondeling)}

Op 11 maart 2020 heeft Karel de Greef een voordracht gehouden voor de Coöperatie Zuid-Oost Salland met betrekking tot afkeuring van vleeskonijnen aan de slachtlijn. Hiervan is een PowerPoint beschikbaar.

\section{Output}

- $\quad$ Greef, K.H. de \& J.M. Rommers (2018b). Afkeuringen bij vleeskonijnen - oproep aan konijnenhouders. KonijnenWijzer 36-2: p.30.

- $\quad$ Arts H., K.H. de Greef \& J.M. Rommers (2018). Project afkeuringen bij de vleeskonijnen. KonijnenWijzer 36-4: p.8-9.

- $\quad$ Greef K. de, 2020. Afkeuringen aan de slachtlijn. PowerPoint t.b.v. voordracht Coöperatie ZOSalland, gehouden op 11 maart 2020.

\subsubsection{Gezondheid: Voermanagement in relatie tot darmgezondheid / antibioticareductie}

\section{Aanleiding}

Binnen de commerciële konijnenhouderij geldt dat er gestreefd moet worden naar een vermindering van het antibioticagebruik. De grootste impact is te verwachten bij de speenkonijnen en in het afmesttraject. "Dikke buikenziekte" is een multifactoriele aandoening die in de afmestperiode ziekteproblemen en uitval veroorzaakt. Naast hygiëne (o.a. werken volgens all-in /all-out) kan het voermanagement invloed hebben op de dikke buiken ziekte en daarom vindt voersturing plaats vanaf spenen om darmproblemen te voorkomen en daarmee het antibioticagebruik terug te dringen. In 2015 is een start gemaakt met onderzoek naar voermanagement. Dit bestond uit een verkenning van te verwachte effecten. De kern van de boodschap uit de verkenning was dat de twee methoden van voermanagement (kwantitatieve en kwalitatieve aanpassing van de voerverstrekking) beide beloftevol zijn om de darmproblematiek (met name dikkebuikenziekte) na het spenen te beperken.

Kwantitatieve methoden bleken al in aanzienlijke mate toegepast te worden in de praktijk. Vanuit de gedachte dat op dit gebied het laaghangend fruit al benut wordt, is door de klankbordgroep besloten zich voor de rest van 2015 te richten op experimenteren met kwalitatieve aanpassing van het voeraanbod. Hiervoor is samenwerking gezocht met Molens van der Velpen, een Belgische mengvoerproducent, een van de grotere leveranciers van de Nederlands konijnenhouderij. Dit onderzoek heeft doorgelopen in 2016 en begin 2017.

\section{Doelstelling}

Doelstelling van het onderzoek is om te komen tot verbetering van de darmgezondheid van vleeskonijnen via aanpassing van voermanagement ten behoeve van anitbioticareductie. Voermanagement kan worden onderverdeeld in sturen op voersamenstelling of voerhoeveelheid. 


\section{Werkwijze en resultaten}

Wetenschappelijk is vastgesteld dat voermanagement de darmgezondheid bevorderd. Bij WLR is in 2015 een start gemaakt met dit onderwerp, dat in 2016 is vervolgd en in 2017 is afgerond. Naast een verkenning in de literatuur en het consulteren van konijnenhouders, dierenartsen en internationale collega's zijn twee proeven uitgevoerd.

In een bijeenkomst met de werkgroep "Zicht op gezonde dieren" zijn de ervaringen met voermanagement geïnventariseerd en is besproken hoe dit onderwerp 'aan te vliegen'. Het thema is ook besproken in een bijeenkomst met de dierenartsen werkzaam in de konijnenhouderij.

De eerste proef betrof een aanpassing van de (speen)voersamenstelling om problemen rond spenen te verminderen. Vraagstelling was: "kan door aanpassing van de (speen)voersamenstelling het optreden van problemen rond spenen verminderd worden? Vanaf dag 20 is een aangepast speenvoer vergeleken met regulier speenvoer. Hierbij is het experimentele voer door de voerleverancier zodanig geformuleerd dat het darmstelsel van de jongen ontlast, maar tegelijkertijd de voedster voldoende ondersteunt voor de combinatie van dracht en lactatie. Tevens is onderzocht of aanpassing van het overschakelmoment van speenvoer naar afmestvoer perspectieven biedt. In strijd met de verwachting gaf het Lactospeenvoer een hogere groei tijdens de lactatie te zien. Deze voorsprong werd na het spenen weer teniet gedaan door de hogere groeisnelheid van de controlegroep (regulier speenvoer). Er waren geen noemenswaardige effecten waarneembaar op uitval of verliesdagen. Ook aanpassen van het overschakelmoment op mestvoer had geen aantoonbare voordelen voor de gezondheid van de betreffende dieren.

De tweede proef omvatte een studie op een praktijkbedrijf waar zowel op tijd als hoeveelheid gevoerd kon worden. Op een bedrijf waar relatief geavanceerde apparatuur voor voerverstrekking beschikbaar is (registratie van verstrekte hoeveelheid plus mogelijkheden om in tijd te sturen) is gedurende een drietal ronden een vergelijking gemaakt tussen de standaard strategie en een strategie waarbij de verstrekte voerhoeveelheid in het tweede deel van de mestperiode $10 \%$ gereduceerd werd. Doordat de uitval van vleeskonijnen op dit bedrijf laag lag, konden geen effecten van de voersturing op de uitval worden vastgesteld. De groeiderving door de voerbeperking was minimaal.

\section{Outcome}

Dit thema heeft bevestigd dat de grootste effecten van voermanagement te behalen zijn met kwantitatieve voersturing, en dat dit grotendeels al verwezenlijkt is. Dit thema heeft in de PPS geen verdere aandacht meer gehad (op advies van de begeleidingscommissie). Het grootste effect was bereikt en de experimenten met voersamenstelling boden te weinig perspectief voor de PPS. Deze invalshoek wordt overgelaten aan de industrie.

\section{Communicatie (mondeling)}

Twee bijeenkomsten in workshop-setting: met de werkgroep "Zicht op gezonde dieren" en met de dierenartsen werkzaam in de konijnenhouderij.

Output

- $\quad$ Rommers J.M., Greef K.H. de, Hattem T.G. van, 2016. Wanneer schakel je vleeskonijnen na spenen over op afmestvoer? KonijnenWijzer, jaargang 34, november: 13-19.

- $\quad$ Rommers J.M., Greef K.H. de, Hattem T.G. van, 2016. Geeft lactospeenvoer een betere start voor de afmestperiode? KonijnenWijzer, jaargang 34, mei: 17-19.

- $\quad$ Greef K. de, 2017. PowerPoint ten behoeven van de bijeenkomst werkgroep "Zicht op gezonde dieren" t.b.v. voermanagement vleeskonijnen gehouden op 25 januari 2017. 


\subsection{Thema Markt en sectorontwikkeling}

\subsubsection{Markt- en sector ontwikkeling: Beter Leven Keurmerk Dierenbescherming}

\section{Aanleiding}

Een van de kerndoelen van de PPS is om welzijnsverbeteringen ontwikkeld, getoetst en geïntroduceerd te krijgen. Naast het (dier/houderij-)technische aspect zijn ook markt- en sectoraspecten hiervoor relevant. Daarom is in de PPS een werkpakket Markt- en sectorontwikkeling toegevoegd. Vanuit dit werkpakket is ondersteuning en begeleiding aan sector, marktpartijen en DB verleend vanuit de PPS. Hierbij was de certificering en introductie van groepshuisvesting voedsters via het Beter Leven keurmerk het meest prominente item.

\section{Werkwijze en resultaten}

In 2013 is door WLR en de Dierenbescherming verkend wat de contouren zouden kunnen zijn voor een vernieuwd één ster Beter Leven keurmerk voor konijnen. Aansluitend op de experimentele toetsing van parttime groepshuisvesting zijn in 2017, in samenspraak tussen sector, afnemer en de Dierenbescherming, nieuwe voorwaarden opgesteld om te komen tot een Beter Leven Keurmerk (BLK) met één ster voor vleeskonijnen. De voorwaarden van BLK zijn op een praktijkbedrijf getoetst in een pilot. In deze pilot zouden twee ronden (van mengen van de voedsters tot aan spenen) de effecten van groepshuisvesting worden gemonitord op huidbeschadigingen en uitval. Echter aan het begin van de tweede ronde werd dit bedrijf getroffen door een VHD-type 2 uitbraak. Dit maakte verdere monitoring niet mogelijk. De eerste ronde gaf minder huidbeschadigingen (2-3\%) dan in de proef die eerder is uitgevoerd. De monitoring is in 2018 voortgezet.

Werkbezoek Prof. Szendrö (Hongarije) en de heer Odermatt (Zwitserland) Op 29 juli 2019 heeft Jorine Rommers overleg gehad met de heren Szendrö en Odermatt. Het betrof parttime groepshuisvesting van voedsters en het standpunt van de Dierenbescherming hierin. Beide heren waren in Nederland ter marktoriëntatie bij een grote retail-organisatie.

\section{Outcome}

De belangrijkste outcome van de PPS is dat er een ontwikkeld, getoetst en BLK-gecertificeerd systeem voor het houden van voedsters in groepen is. Dit systeem is inmiddels de standaard voor een van de marktpartijen. Inmiddels lopen er meerdere initiatieven parallel (privaat - buiten bestek van de PPS)

\section{Output}

- $\quad$ Rommers J. en de Greef K., 2017. Towards part-time group-housing of lactating rabbit does? PowerPoint t.b.v. overleg met de Dierenbescherming en AH op 18 juli 2017.

- $\quad$ Rommers J. en de Greef K., 2017. PowerPoint t.b.v. overleg met de Dierenbescherming, $A H$, LTO, Luitenfood en fam Slegh op 1 augustus 2017.

- $\quad$ Kool A., 2019. Beter Leven Keurmerk 1 ster. Konijnenwijzer 37, 1: 28.

\subsubsection{Markt- en sector ontwikkeling: Algemeen}

Vanuit de het werkpakket Sector- en marktontwikkeling is enkele malen input geleverd om ketenpartijen en LTO te ondersteunen bij het formuleren van hun toekomstvisies en strategie.

\section{$2.4 \quad$ Internationaal}

Internationaal hebben er vanuit de konijnenportefeuille diverse activiteiten plaatsgevonden. De belangrijkste items die direct aan de PPS gerelateerd zijn worden hier aangestipt. 


\subsubsection{Internationaal: Congresbijdrages WRC en Celle}

In 2016 heeft het World Rabbit Congres plaats gevonden in Qingdao, China. Op het wereldcongres is de verduurzamingsstrategie van de sector (met nadruk op het welzijnsspoor) gepresenteerd. Ook is een experiment binnen het onderzoek naar gezondheidsverbetering (de mengproef binnen de systeemvergelijking) gepresenteerd en besproken.

Als voorbereiding voor de World Rabbit Conference (Nantes, F, juli 2020) zijn drie wetenschappelijke bijdragen geschreven: betreffende het voetzoolonderzoek en een analyse van de welzijns-gerichte innovatieprocessen in de laatste twee decennia en rond RVHD2 in Nederland en Duitsland. Daarnaast is een ronde tafel conferentie m.b.t. afkeuringen van vleeskonijnen door Karel de Greef voorbereid. Het WRC in Nantes, Frankrijk dat in 2020 gehouden zou worden, is in verband met de Coronaproblematiek uitgesteld naar juni 2021.

Eenmaal per twee jaar wordt in Celle het Symposium for Housing and Diseases of Rabbits, Furproviding Animals and Pet Animals georganiseerd. In 2017 vond het congres plaats op 17 en 18 mei. Vanuit WLR heeft Jorine Rommers deelgenomen aan dit congres. Zij heeft de resultaten van de in 2016 uitgevoerde pilots naar mogelijkheden van groepshuisvesting van voedsters in een oral presentation uitgedragen. Van dit congres zijn proceedings verschenen. Daarnaast is er een artikel over de inhoud van dit congres in de KonijnenWijzer verschenen.

Output

- $\quad$ Arts H.T., Arts B., Rommers J., accepted. Rabbit Heamorrhagic disease virus type 2 (RHVD2) in The Netherlands and Germany: clinical and epidemiological findings. Paper t.b.v. World Rabbit Congres in Nantes, Frankrijk juni 2021.

- $\quad$ Rommers J.M., Greef K.H. de, 2016. Are pre-weaning health problems transferred to later phases in PARC housed meat rabbits? In: Proceedings of the 11th world rabbit congress, Qingdao, June 15-18, 2016, Q. Yinghe, L. Fuchang and T. Gidenne (eds), p. 579-582. (ook genoemd bij Gezondheid: Mengen van jongen uit goede en slechte nesten).

- $\quad$ Karel de Greef K.H. de, Rommers J. and Lavrijsen S., 2016. Market and society driven innovations in the Dutch Rabbit production system. In: Proceedings of the 11th world rabbit congress, Qingdao, June 15-18, 2016, Q. Yinghe, L. Fuchang and T. Gidenne (eds).

- $\quad$ Rommers J. and de Greef K., 2017. Towards part-time group-housing of lactating rabbit does? In: Proceedings 20th International Symposium of housing and diseases of rabbits, furproviding animals and pet animals, 17-18 May, Celle: 3-13. (Ook genoemd bij Huisvesting: Parttime groepshuisvesting van voedsters).

- $\quad$ Rommers J.M., 2016. Verslag 19e Internationale Tagung uber Haltung and Krankheiten der Kaninchen, Pelztiere und Heimtiere. Konijnenwijzer, jaargang 34, februari: 9-11.

- $\quad$ Rommers J. and Karel de Greef, accepted. Are plastic mats effective for diminishing footpad lesions of rabbit does? - Survey after 10 years in The Netherlands. Paper t.b.v. WRC in Nantes, Frankrijk in juni 2021 (Ook genoemd bij Gezondheid: voetzoolbeschadigingen bij voedsters).

- $\quad$ de Greef K., Rommers J., accepted. The Dutch route to improve commercial rabbit welfarerather collective than by law enforcement. Paper t.b.v. WRC in Nantes, Frankrijk in juni 2021.

\subsubsection{Internationaal: WRSA studiemiddagen Nederland-Belgie}

Voordracht tijdens de World Rabbit Science Association (WRSA) studie dag Nederland/België. Jaarlijks houden de WRSA afdeling Nederland en België een gezamenlijke studiedag. In 2017 werd verslag gedaan van het in 2016 gehouden Wereldcongres van de WRSA in China. Namens WLR heeft Karel de Greef deelgenomen aan dit congres en deed verslag van de sessie "Housing, welfare en management. Naast het verslag van het wereldcongres is op deze studiemiddag ook een overzicht gegeven van het lopende onderzoek bij WLR door Karel de Greef en Jorine Rommers. Van beide voordrachten is er een PowerPoint.

In 2018 is verslag gedaan van de buitenlandse onderzoeksdagen in Duitsland en Frankrijk en is het onderzoek binnen de PPS toegelicht. Van beide presentaties is een PowerPoint. 
In 2019 zijn de voorlopige resultaten van het voetzoolonderzoek zijn gepresenteerd en bediscussieerd.

Tevens zijn de hoofdlijnen van de Nederlandse onderzoeksaanpak binnen de PPS benoemd.

Output

- $\quad$ de Greef K. en Rommers J., 2017. Lopend onderzoek in Nederland. PowerPoint t.b.v. studiemiddag WRSA afdeling Nederland/België gehouden op 8 maart 2017.

- $\quad$ Rommers J., 2018. Verslag buitenlandse onderzoeksdagen: Duitsland (J. Rommers) en Frankrijk (L. Maertens). WRSA-studiebijeenkomst april 2018 PowerPoint.

- Greef K.H. de, 2018. Onderzoek Wageningen Livestock Research. WRSA-studiebijeenkomst april 2018 PowerPoint.

- De Greef en Rommers, 2019. Het vóórkomen van voetzoolproblemen bij commerciële konijnen op Nederlandse bedrijven. Voorlopige resultaten. Bijdrage op de gezamenlijke studiedag WRSA voor de Belgische en Nederlands leden. (Ook genoemd bij Gezondheid: voetzoolbeschadigingen bij voedsters).

\subsubsection{Internationaal: Raad Dierenwelzijn België}

De Belgische Raad voor Dierenwelzijn heeft zich verdiept in de implementatie van enkele Koninklijke Besluiten rond het huisvesten van konijnen gehouden voor vleesproductie. Het betrof parkhuisvesting van vleeskonijnen en groepshuisvesting van voedsters met jongen. Karel de Greef is hierin afgevaardigd vanwege de ervaringen en onderzoekingen in Nederland. De groep (met afvaardigingen uit de sector, ministerie, verwerkende industrie en een NGO) is drie maal fysiek bijeen geweest rond deze thema's. De Nederlandse resultaten en visies zijn gedeeld en besproken.

\section{Outcome}

Het Vlaamse ministerie van Landbouw heeft ILVO (Belgisch onderzoeksinstituut) opdracht gegeven enkele thema's van groepshuisvesting voor voedsters nader te onderzoeken alvorens tot implementatie over te gaan. Dit onderzoek afgestemd op de in Nederland beschikbaar gekomen resultaten. Geconcludeerd is dat afstemming tussen België en Nederland (zowel sectoraal als ministerieel) nodig is om de aansluiting tussen wenselijke productieomstandigheden en mogelijkheden/eisen in de markt aangesloten te houden.

Output

Rapportages Belgische Raad voor Dieraangelegenheden (intern).

\subsubsection{Internationaal: Samenwerking en begeleiding ILVO, België}

$\mathrm{Er}$ is sinds de negentiger jaren regelmatig afgestemd tussen de Nederlandse en de Belgische collegaonderzoekers van het ILVO te Merelbeke, waar Ir. Luc Maertens projectleider was van het Belgische konijnenonderzoek. In oktober 2016 hield Luc Maertens zijn afscheid op het ILVO in Merelbeke, België. Jorine Rommers hield als gastspreker een inleiding op dit symposium dat ter gelegenheid van zijn pensionering was georganiseerd. Zwaartepunt van de samenwerking betrof het verbeteren van de huisvesting en het welzijn van voedsters en vleeskonijnen.

Met de pensionering van Luc Maertens aan het ILVO in België is veel kennis weggevallen. Sinds 2019 wordt er gewerkt aan een vierjarig project met betrekking tot groepshuisvesting van voedsters door promovenda ir Liesbeth van Damme. Vanuit WLR wordt zij ad-hoc geadviseerd en wordt deelgenomen in de begeleidingscommissie.

\section{Outcome}

Ondanks het vertrek van de 'prime investigator' is de samenwerking tussen WLR en ILVO gecontinueerd. De thema's van onderzoek vertonen dermate veel aansluiting dat deze samenwerking belangrijk is voor de Nederlandse (en Belgische) sector en onderzoeksagenda.

Output

- Rommers J., 2016. Samenwerking en overleg: het konijnenonderzoek. Bijdrage t.g.v. het afscheid van Luc Maertens, senior onderzoeker ILVO, Merelbeke, België. 


\subsubsection{Internationaal: Bezoek Zollikhofen, Zwitserland}

In 2019 heeft Jorine Rommers een bezoek gebracht aan het onderzoeksinstituut in Zollifhofen en heeft daar aan de Universiteit te Bern een presentatie gehouden over het parttime groupshuisvestings onderzoek gericht op het verminderen van huidbeschadigingen.

\section{Output}

- $\quad$ Rommers J., de Jong I.C en de Greef K.H., 2019. Housing adaptations to control group aggression among rabbit does: the Dutch approach. Presentatie gehouden op 19-4-2018.

\subsection{Communicatie overig}

\subsubsection{Communicatie overig: Begeleidingscommissie PPS}

Output

- $\quad$ Greef, de K., Overzicht onderzoek 2015. PowerPoint t.b.v. Begeleidingscommissie gehouden januari 2016.

- $\quad$ Rommers J en de Greef K., 2017. PowerPoint t.b.v. Begeleidingscommissie gehouden 12 september 2017.

- $\quad$ Rommers en de Greef, 2018: Parttime groepshuisvesting voedsters, onderzoek 2016-2017. PowerPoint t.b.v.. Overleg LTO gehouden 3 april 2018.

\subsubsection{Communicatie overig: Overige publicaties vakbladen}

Output

- $\quad$ Greef, K.H. de \& J.M. Rommers (2018a). Het onderzoek in 2018. KonijnenWijzer 36-1: 7-9.

- $\quad$ Greef, K.H. de \& J.M. Rommers (2018c). Update vanuit het onderzoek. KonijnenWijzer 36-4: 10-11.

- $\quad$ Rommers J.M. en de Greef K.H., 2020. Highlights internationaal onderzoek konijnen. KonijnenWijzer 38, 1.

- $\quad$ Greef K.H., 2021. PPS 2016-2020 is afgelopen.... KonijnenWijzer 39-1: p. 21.

\subsection{Nieuwe PPS 2021-2025 (brainstormsessies vitaliteit jonge dieren)}

Wageningen Livestock Research heeft (in opdracht van, en in nauwe samenwerking met LTO) een voorstel geschreven voor de onderzoeks-invulling 2021-2025. In deze nieuwe PPS staan twee thema's centraal, die beide zowel relevant zijn voor de sector als ook maatschappelijk gevraagd worden. Dit betreft jongdierzorg en langetermijn-toekomstperspectief voor jonge ondernemers/gezinsbedrijven.

De invulling betreffende jongdierzorg wordt gegeven in de vorm van veel kleine verkenningen en proefjes die gedaan worden om te onderzoeken of de jongdierzorg verbeterd kan worden om zo de sterfte te verlagen en sterkere konijnen te spenen. Dit wordt gedaan op de bedrijven van 8 jonge konijnenhouders. Daarnaast wordt een aantal studieavonden georganiseerd waarin belangrijke thema's die de langetermijn-toekomst van bedrijven bepalen aan de orde komen.

Ter voorbereiding op de nieuwe PPS zijn brainstormsessies gehouden en is een korte literatuur search uitgevoerd. De abstracts van enkele relevante wetenschappelijke artikelen zijn weergegeven in een Word document (intern). 


\section{Outcome}

Deze nieuwe PPS is inmiddels goedgekeurd en is inmiddels gestart (januari 2021). Ten behoeve van informatieverstrekking aan de konijnensector is een artikel m.b.t. de nieuwe PPS in de KonijnenWijzer gepubliceerd.

Output

- $\quad$ Greef K. de, 2020. Projectbeschrijving nieuwe PPS 2021-2025 (zorg voor dieren).

- $\quad$ Greef K.H. de en Rommers J.M., 2020. Gezamenlijk onderzoek in de konijnenhouderij 20212025. Konijnenwijzer 38, 4: 23.

- $\quad$ Korte literatuursearch met betrekking tot jongensterfte (intern). 


\section{Bijlage 1 Verzamelde output}

\section{(Semi) Wetenschappelijke artikelen}

- Arts H.T., Arts B., Rommers J., accepted. Rabbit Heamorrhagic disease virus type 2 (RHVD2) in The Netherlands and Germany: clinical and epidemiological findings. Paper t.b.v. World Rabbit Congres in Nantes, Frankrijk juni 2021.

- Greef K.H. de, Rommers J.M., Lavrijssen S, 2016. Market and society driven innovations in the Dutch rabbit production system. In: Proceedings of the 11th world rabbit congress, Qingdao, June 15-18, 2016, Q. Yinghe, L. Fuchang and T. Gidenne (eds), p. 953-956.

- de Greef K., Rommers J., accepted. The Dutch route to improve commercial rabbit welfare- rather collective than by law enforcement. Paper t.b.v. WRC in Nantes, Frankrijk in juni 2021.

- Rommers J.M., Greef K.H. de, 2016. Are pre-weaning health problems transferred to later phases in PARC housed meat rabbits? In: Proceedings of the 11th world rabbit congress, Qingdao, June 15-18, 2016, Q. Yinghe, L. Fuchang and T. Gidenne (eds), p. 579-582.

- Rommers J. and Greef K. de, 2017. Towards part-time group-housing of lactating rabbit does? In: Proceedings 20th International Symposium of housing and diseases of rabbits, furproviding animals and pet animals, 17-18 May, Celle: 3-13.

- Rommers J. and de Greef K., 2017. Towards part-time group-housing of lactating rabbit does? In: Proceedings 20th International Symposium of housing and diseases of rabbits, furproviding animals and pet animals, 17-18 May, Celle: 3-13.

- Rommers, J.M. and Greef, K.H. de, 2018. Are combi parks just as useful as regular parks for fatteners for part-time group housing of rabbits does? World Rabbit Science 26: 299 - 305.

- Rommers J.M. and de Greef K.H., accepted. Are plastic mates effective for diminishing footpad lesions of rabbit does? - Survey after 10 years in The Netherlands. World Rabbit Congres bijdrage, Nantes juni 2021.

\section{Rapporten/Notities}

- Eijkelenboom N., 2016. The development and use of a hygiene assessment system in a commercial rabbit farm. Stageverslag, Universiteit Utrecht, Faculteit Diergeneeskunde.

- Greef K. de, 2020. Projectbeschrijving nieuwe PPS 2021-2025 (zorg voor dieren).

- Laarhoven J., 2020. The Effect of Mixing Kits from Poor and Healthy Litters on Post-Weaning Mortality in Parc-Housed Fattening Rabbits. MSc thesis, WUR.

- Rommers J., de Jong I., Houwers W., van Hattum T., de Greef K., 2017. Evaluatie van parkhuisvestingssystemen voor vleeskonijnen. WLR Rapport 1018.

\section{Artikelen in vakbladen}

1. Arts H., K.H. de Greef \& J.M. Rommers, 2018. Project afkeuringen bij de vleeskonijnen. KonijnenWijzer 36-4: p.8-9.

2. Arts H., Claessens A., Willems J., 2021. Bescherming tegen RVHD type 2. Konijnenwijzer 39-1 (februari): p. 13-15.

3. Eijkelenboom N., 2016. Stagerapportage: Hygiëne in de konijnenhuisvesting. KonijnenWijzer, jaargang 34, augustus: 7-8.

4. Greef, K.H. de \& J.M. Rommers, 2018a. Het onderzoek in 2018. Konijnenwijzer 36-1: p.7-9.

5. Greef, K.H. de \& J.M. Rommers, 2018b. Afkeuringen bij vleeskonijnen - oproep aan konijnenhouders. KonijnenWijzer 36-2: p.30. 
6. Greef, K.H. de \& J.M. Rommers, 2018c. Update vanuit het onderzoek. Konijnenwijzer 36-4: p.1011.

7. De Greef K., 2020. RVHD2: Vier samen weten meer dan een alleen..... Konijnenwijzer 38, 4: 30.

8. Kool A., 2019. Beter Leven Keurmerk 1 ster. KonijnenWijzer 37, 1: 28.

9. Rommers J.M., 2016. Verslag 19e Internationale Tagung uber Haltung and Krankheiten der Kaninchen, Pelztiere und Heimtiere. KonijnenWijzer, jaargang 34, februari: 9-11.

10. Rommers J.M., Greef K.H de, Houwers H.W.J., Hattem T.G. van, 2016. Goed ogende konijnen uit slechte nesten wat doen we ermee in parkhuisvesting? KonijnenWijzer, jaargang 34, mei: 10-12.

11. Maertens L., Rommers J.M., 2016. Het huisvesten van vleeskonijnen in parken. KonijnenWijzer, jaargang 34, mei: 14-15.

12. Rommers J.M., Greef K.H. de, Hattem T.G. van, 2016. Wanneer schakel je vleeskonijnen na spenen over op afmestvoer? KonijnenWijzer, jaargang 34, november: 13-19.

13. Rommers J.M., Greef K.H. de, Hattem T.G. van, 2016. Geeft lactospeenvoer een betere start voor de afmestperiode? KonijnenWijzer, jaargang 34, mei: 17-19.

14. Rommers J., 2017. Voedsters en groepshuisvesting? Mogelijkheden en knelpunten op basis van gedrag. KonijnenWijzer, jaargang 35, februari 2017: 14-19.

15. Rommers J., de Jong I., de Greef K., 2017. Evaluatie van parkhuisvesting van vleeskonijnen. Voldoen de parksystemen aan de behoeften van konijnen? KonijnenWijzer, jaargang 35, mei 2017: 7-11.

16. Rommers J., Gunnink H., van Hattum T., de Greef K., 2017. Evaluatie van parkhuisvesting van vleeskonijnen. Hoe presteren de konijnen in de verschillende parksystemen? KonijnenWijzer, jaargang 35, mei 2017: 13-17.

17. Rommers J. en de Greef K., 2017. Parttimegroepshuisvesting van voedsters, pilotonderzoek. KonijnenWijzer, jaargang 35, augustus 2017: 8-11.

18. Verschillen de parksystemen in hygiëne en reinigbaarheid? KonijnenWijzer, jaargang 35 , augustus 2017: 13-17.

19. Rommers J., de Greef K., 2017. Evaluatie van parkhuisvesting van vleeskonijnen. Verschillen de parksystemen in werkbaarheid? KonijnenWijzer, jaargang 35, augustus 2017: 19-21.

20. Rommers J., 2017. Verslag 20th Symposium on housing and diseases of rabbits, furproviding animals and pet animals. KonijnenWijzer, jaargang 35, november 2017: 25-27.

21. Rommers, J.M. \& K.H. de Greef, 2018. Zijn combi-parken even geschikt als parken voor parttime groepshuisvesting van voedsters? KonijnenWijzer 36-1: p.10-13.

22. Rommers, J.M. \& M. Kuijpers, 2018. Studiemiddag WRSA afdeling Nederland op 11 april 2018. KonijnenWijzer 36-3: p.11-13.

23. Rommers J.M. en K.H. de Greef, 2019. Opgang komen met groepshuisvesting van voedsters vraagt maatwerk. KonijnenWijzer 37, februari: 23.

24. Rommers J.M. en K.H. de Greef, 2019. Voetzoolbeschadigingen: een evaluatie na 10 jaar kunststof matjes. KonijnenWijzer, augustus: 17.

25. Rommers J. en de Greef K., 2020. Highlights internationaal onderzoek konijnen. KonijnenWijzer 38, 1: 18-19.

26. Greef K.H. de en Rommers J.M., 2020. Gezamenlijk onderzoek in de konijnenhouderij 2021-2025. Konijnenwijzer 38, 4: 23.

27. Greef K.H., 2021. PPS 2016-2020 is afgelopen.... KonijnenWijzer 39-1: p. 21.

\section{Inleidingen/ workshops}

1. Greef, K. de, 2016. Overzicht onderzoek 2015. PowerPoint t.b.v. begeleidingscommissie gehouden januari 2016.

2. Greef, K. de en Rommers J., 2017. Lopend onderzoek in Nederland. PowerPoint t.b.v. studiemiddag WRSA afdeling Nederland/België gehouden op 8 maart 2017.

3. Greef, K. de, 2017. PowerPoint ten behoeven van de bijeenkomst werkgroep "Zicht op gezonde dieren" t.b.v. voermanagement vleeskonijnen gehouden op 25 januari 2017.

4. Greef, K. de 2018. Onderzoek Wageningen Livestock Research. WRSA-studiebijeenkomst april 2018. 
5. Greef, K.de, 2019. Het vóórkomen van voetzoolproblemen bij commerciële konijnen op Nederlandse bedrijven. Voorlopige resultaten. Bijdrage op de studiedag WRSA Nederland-België op 17-4-2019.

6. Greef K. de, 2020. Afkeuringen aan de slachtlijn. PowerPoint t.b.v. voordracht Coöperatie ZOSalland, gehouden op 11 maart 2020.

7. Rommers J. en de Greef K., 2016. Voedsters en groepshuisvesting? Mogelijkheden en knelpunten op basis van gedrag. Studiebijeenkomst VOK op 24 november 2016.

8. Rommers J., 2016. Samenwerking en overleg: het konijnenonderzoek. Bijdrage t.g.v. het afscheid van Luc Maertens, senior onderzoeker ILVO, Merelbeke, België.

9. Rommers J en de Greef K., 2017. PowerPoint t.b.v. Begeleidingscommissie gehouden 12 september 2017.

10. Rommers J. en de Greef K., 2017. Evaluatie van parkhuisvesting voor vleeskonijnen. PowerPoint t.b.v. studieclub konijnenhouders gehouden op 17 januari 2017.

11. Rommers J., en de Greef K., 2017. PPS Duurzame konijnenhouderij. PowerPoint t.b.v. het Afdelingsoverleg Afdeling Dierenwelzijn WLR op 6 juni 2017.

12. Rommers J. en de Greef K., 2017. Towards part-time group-housing of lactating rabbit does? PowerPoint t.b.v. overleg met de Dierenbescherming en $\mathrm{AH}$ op 18 juli 2017.

13. Rommers J. en de Greef K., 2017. PowerPoint t.b.v. overleg met de Dierenbescherming, AH, LTO, Luitenfood en fam Slegh op 1 augustus 2017.

14. Rommers en de Greef, 2018. Parttime groepshuisvesting voedsters, onderzoek 2016-2017. PowerPoint t.b.v. Overleg LTO gehouden 3 april 2018.

15. Rommers J., 2018. Verslag buitenlandse onderzoeksdagen: Duitsland (J. Rommers) en Frankrijk (L. Maertens). WRSA-studiebijeenkomst april 2018.

16. Rommers J., de Jong I.C en de Greef K.H., 2019. Housing adaptations to control group aggression among rabbit does: the Dutch approach. Presentatie gehouden op 19-4-2018. 


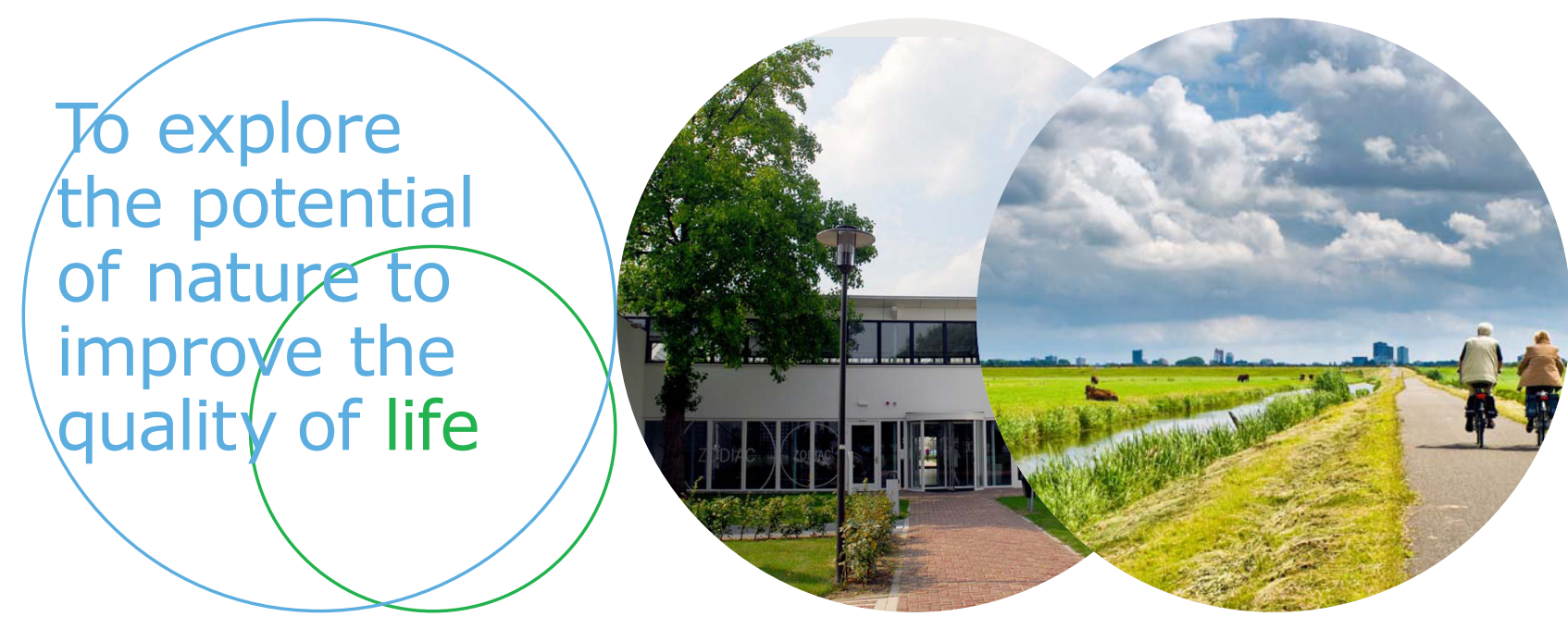

Wageningen Livestock Research Postbus 338

$6700 \mathrm{AH}$ Wageningen

T 0317483953

E info.livestockresearch@wur.nl www.wur.nl/livestock-research
Wageningen Livestock Research ontwikkelt kennis voor een zorgvuldige en renderende veehouderij, vertaalt deze naar praktijkgerichte oplossingen en innovaties, en zorgt voor doorstroming van deze kennis. Onze wetenschappelijke kennis op het gebied van veehouderijsystemen en van voeding, genetica, welzijn en milieu-impact van landbouwhuisdieren integreren we, samen met onze klanten, tot veehouderijconcepten voor de $21 \mathrm{e}$ eeuw.

De missie van Wageningen University \& Research is 'To explore the potential of nature to improve the quality of life'. Binnen Wageningen University \& Research bundelen 9 gespecialiseerde onderzoeksinstituten van Stichting Wageningen Research en Wageningen University hun krachten om bij te dragen aan de oplossing van belangrijke vragen in het domein van gezonde voeding en leefomgeving. Met ongeveer 30 vestigingen, 6.500 medewerkers en 10.000 studenten behoort Wageningen University \& Research wereldwijd tot de aansprekende kennisinstellingen binnen haar domein. De integrale benadering van de vraagstukken en de samenwerking tussen verschillende disciplines vormen het hart van de unieke Wageningen aanpak. 